\title{
INTRODUCTION OF AN INDIVIDUAL AIRCRAFT TRACKING PROGRAM FOR THE POLISH SU-22
}

\author{
Piotr Reymer ${ }^{1}$, Marcin Kurdelski ${ }^{1}$, Andrzej Leski ${ }^{2}$, Andrzej Leśniczak ${ }^{1}$, \\ Michal Dziendzikowski ${ }^{1}$
}

${ }^{1}$ Air Force Institute of Technology, Ks. Bolestawa 6, 01-494 Warsaw, Poland

${ }^{2}$ Institute of Aviation, Al. Krakowska 110/114, 02-256 Warsaw, Poland

\begin{abstract}
The Su-22 fighter-bomber is a military aircraft used in the Polish Air Force (PLAF) since the mid 1980's. By decision of the Ministry of National Defence Republic of Poland, the assumed service life for this type of aircraft was prolonged up to 3200 flight hours based on the Full Scale Fatigue Test (FSFT) results. The FSFT was conducted using the real load profile defined during the Operational Load Monitoring Program (OLM) and the 3200 hour service life was also based on this load profile.

In order to assure safe operation of all the 18 Su-22 aircraft, the Individual Aircraft Tracking program was introduced. The program was based on the results of the FSFT as well as the analysis of the flight parameters recorded by the THETYS onboard flight recorder.

In this paper, the authors present the methodology, assumed fatigue hypothesis and preliminary results of the IAT program for the Polish Su-22.
\end{abstract}

Keywords: Individual Aircraft Tracking, Su-22 fighter-bomber.

\section{INTRODUCTION}

The Su-22 is a variable sweep wing fighter-bomber which has been operated by the Polish Air Force (PLAF) since mid-1980's. There are two versions of the aircraft: single-seated combat version M4 and a two-seated trainer UM3K. The total length of the aircraft is $19 \mathrm{~m}$ and the Take-Off Gross Weight (TOGW) is $19500 \mathrm{~kg}$. The outer wing sweep angle can be changed from $30^{\circ}$ for take-off and landings through $45^{\circ}$ for subsonic flights, to $63^{\circ}$ for supersonic flights. The wing sweep angle affects the wing span, which ranges from 10 to $13.7 \mathrm{~m}$ as well as the wing area, which ranges from 34.15 to $38.49 \mathrm{~m}^{2}$. Vertical overload approved by the manufacturer is in the range of -2 to 6 . 
By decision of the Ministry of National Defence Republic of Poland the service life of the Su-22 was to be prolonged up to 3200 Flight Hours (FH) and 6000 landings. In order to achieve that goal the Service Life Extension Program (SLEP) for the Polish Su-22 was undertaken. The most important task of the program, from the structural point of view, was the Full Scale Fatigue Test (FSFT). According to the technical requirements $[1,2]$ during the test structural loads were exerted on the aircraft structure by means of hydraulic actuators. The load spectra were generated based on the Operational Load Monitoring program (OLM). Due to the limited time to perform the test as well as the laborious procedure for changing wing sweep and rearranging actuators, it was decided to divide the test into four stages including: landing loads, flight loads, flap loads and flight loads up to critical failure.

The results of the test, described in the following sections, were crucial for the definition of the total fatigue life of the structure for the purpose of the IAT program.

\section{RESULTS OF THE FULL SCALE FATIGUE TEST}

The FSFT was carried out on a taken out of service aircraft which had already performed 3127 landings and $1583 \mathrm{FH}$. Prior to the test the aircraft was carefully examined using visual, eddy current and ultrasonic Non Destructive Inspections (NDI), during which only some corrosion and minor damages in non-flight critical structural components were found.

The test was divided into four stages, between which the wing sweep angle was set according to the next stage loads ( $30^{\circ}$ for take-off, landing and flap loads, $45^{\circ}$ for flight loads). Moreover, the NDI inspections were carried out after completion of each Stage as well as after completion of $60 \%$ of Stage I and $70 \%$ of Stage II. The inspections resulted in finding minor damages (cracks in access covers, loose fasteners etc.), none of which being flight critical [3].

The critical damage occurred during the final part of Stage IV, in which the constant amplitude load ranging from 1 to 6 vertical overload was applied. The main objective of this Stage was to develop a critical damage to the primary structure of the aircraft and it resulted in cracking the right wing main spar lower flange (Figure 1). 

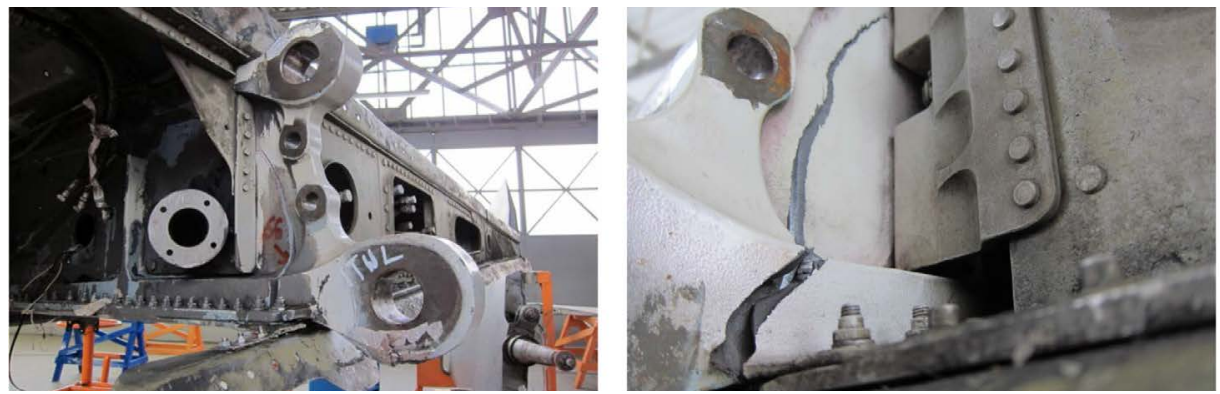

Fig. 1. Critical damage in the Full Scale Fatigue Test

\section{DEFINITION OF THE FATIGUE MODEL}

After accomplishing the FSFT it was possible to define the total fatigue life of the specimen. The gathered historical service flight data as well as the loads carried out during the FSFT were combined in order to develop a full load history.

Since the aircraft was designed as a Safe Life structure, the Palmgren-Miner linear damage hypothesis [4] was chosen to define the fatigue usage. The basic formula is shown in Equation 1, where $n_{i}$ is the number of cycles that occurred at $i$-th level, $N_{i}$ is the total number of cycles at $i$-th level that the structure can withstand until failure, $i$ is the index number and $k$ is the total number of different cycles. The basic concept of the rule is that when the sum, damage index, reaches value $C$ (usually 1), the specimen will fail.

$$
\sum_{i=1}^{k} \frac{n_{i}}{N_{1}}=C
$$

In order to use this theorem it is essential to define the $\mathrm{S}-\mathrm{N}$ curve characteristic for the considered structure. The $\mathrm{S}-\mathrm{N}$ curve defines the number of cycles $\mathrm{N}$ at any i-th level that will cause the considered structure to fail. The S-N curve formula is shown in Equation 2. The $S$ stands for stress amplitude, $N$ is the total number of cycles to failure at this stress amplitude, whereas $a$ and $b$ are experimental constants, characteristic for a given material or structure.

$$
S=a N^{b}
$$

The Su-22 wing spar is made of 30 HGSNA steel alloy and has several bolt holes, from one of which the critical fatigue damage initiated. Therefore the initial S-N curve parameters were chosen from the literature for 30 HGSNA steel alloy with fastener holes [5-7]. 
As $\mathrm{S}-\mathrm{N}$ curve was defined for zero to tension cycles $(\mathrm{R}=0)$ whereas the load spectrum was composed of load cycles with varying amplitudes and mean values, it was therefore essential to be able to represent any cycle in the form of a zero to tension cycle.

The Smith-Watson-Topper criterion [8] was chosen to represent any given initial cycle in terms of a zero to tension cycle. The formula used is presented in Equation 3. $S_{e}$ is the calculated maximum stress of the equivalent zero to tension stress cycle, $\sigma_{a}$ is the amplitude of the input cycle and $\sigma_{m}$ is the mean value of the input cycle.

$$
S_{e}=\sigma_{a}\left(\frac{2}{1-\frac{\sigma_{m}-\sigma_{a}}{\sigma_{m}+\sigma_{a}}}\right)^{0.5}
$$

By combining the above defined dependencies it was possible to evaluate the load history of the test specimen. The main assumption was that the fatigue failure, considered as the value of the cumulative failure index $C$ reaches 1, occurred at the end of Stage IVb. Knowing the load history of each Stage as well as the service loads, the initial values of $b$ constant were slightly modified and the final value was set to $-0,23202$. The resulting fractional fatigue damages are shown in Table 1.

Table 1 Partial fatigue achieved during real operation and consequent Stages of the FSFT

\begin{tabular}{|c|c|c|}
\hline Stage & Partial Fatigue & EFH $[\mathbf{h}]$ \\
\hline Operation & 0.194 & 1702 \\
\hline FSFT Stage II & 0.365 & 3202 \\
\hline FSFT Stage IVa & 0.170 & 1491 \\
\hline FSFT Stage IVb & 0.271 & 2377 \\
\hline Summary & 1.000 & \\
\hline
\end{tabular}

The other main objective was to define the cumulated fatigue index for $3200 \mathrm{FH}\left(D_{3200}\right)$. In the Safe Life approach it is essential to define the Safety Factor (SF), which will incorporate any uncertainties resulting from the fact that the test specimen was more durable than the least durable structure used in operation. Taking into account that during the FSFT two wings were loaded simultaneously (practically two test specimens) as well as the fact that the aircraft were to be operated using the IAT program based on recorded flight 
parameters, the SF of order 2 was chosen. Moreover, it was considered, that the desirable $3200 \mathrm{FH}$ were achieved by the test specimen after completion of Stage IVa. This allowed defining the Equivalent Flight Hours (EFH), which are flight hours in terms of the reference spectrum (also shown in Table 1).

As can be calculated from data in the Table 1, the total number of EFH cumulated by the test specimen after completion of Stage IVa (sum of EFH for Operation, Stage I and Stage IVa) is $6395 \mathrm{EFH}$, which considering the assumed SF corresponds with $3198 \mathrm{EFH}$. The fatigue damage index from Stage IVb and the corresponding $2377 \mathrm{EFH}$ are an additional safety factor. Therefore, the resultant SF for the whole test is equal to 2.74 (ratio of the total number of EFH to the desired $3200 \mathrm{EFH}$ ).

For the partial fatigue damage indexes, corresponding EFH and the assumed $\mathrm{SF}$, the fatigue corresponding to $100 \mathrm{EFH}$ could be defined using the formula shown in Equations 4 and 5.

$$
\begin{gathered}
D_{100 \_ \text {F S F T }}=\frac{D_{\text {Flight }}+D_{I I}+D_{I V a}}{S F * 3200 h} * 100 h \\
D_{100 \_F S F T=}=\frac{0,194+0,365+0,170}{2 * 3200 h} * 100 h=0,0114
\end{gathered}
$$

\section{INDIVIDUAL AIRCRAFT TRACKING - EXEMPLARY RESULTS}

For the defined fatigue model, it was possible to evaluate the actual fatigue damage cumulated by each Su-22 aircraft during operation. The initial analysis was performed for each aircraft after completion of the verification overhaul. This provided a baseline from which the Individual Aircraft Tracking program (IAT) initiated. Using the OLM program results [9-10] the values of vertical overload, recorded by the THETYS onboard flight recorder, were used to define the actual values of stresses in the wing spar lower flange (the Critical Point resulting from the FSFT). These stress values were used to define the corresponding fatigue index of each cycle and using the Palmgren-Miner rule the total fatigue cumulated during the analysis period was calculated.

The IAT analysis uses several indexes which allow the operator to easily evaluate the current usage as well as the total fatigue damage accumulated in each aircraft. First of all, the total damage $D$ accumulated within the analysis period is defined as described above. Secondly, the $D_{3200}$ damage index, defining the percentage of $3200 \mathrm{EFH}$ flown so far, is defined. The $D_{100}$ fatigue damage per $100 \mathrm{EFH}$ is defined using the total damage cumulated during the analyzed 
period $D$ and the number of actual flight hours. The ratio of $D_{100}$ for individual aircraft and $D_{100 F S F T}$ (Equation 5) allows to define the $K_{i e}$, the flight intensity factor, which defines how the operation of an individual aircraft was different from the assumed load profile. Values of $K_{i e}$ exceeding 1 are characteristic for more severely operated aircraft whereas values less than 1 are obtained for less severe operated aircraft.

Knowing the EFH cumulated by each aircraft during operation and EFH corresponding to the currently analyzed time period, it is possible to determine when the aircraft will reach the $3200 \mathrm{EFH}$ service life (taking into account the $K_{i e}$ from the actual period).

Figures 2-4 present some plots from the Su-22 IAT reports. Figure 2 shows the overall fleet status in terms of the total accumulated fatigue damage $D$. Figure 3 depicts the flight intensity factors $K_{i e}$. Noteworthy is the difference in $K_{i e}$ for operation before and after the overhaul for individual aircraft. The final Figure 4 shows an exemplary comparison of cumulated flight profiles before and after overhaul in relation to the FSFT profile normalized to $100 \mathrm{EFH}$. A more severe character of operation after overhaul can be once again noticed.

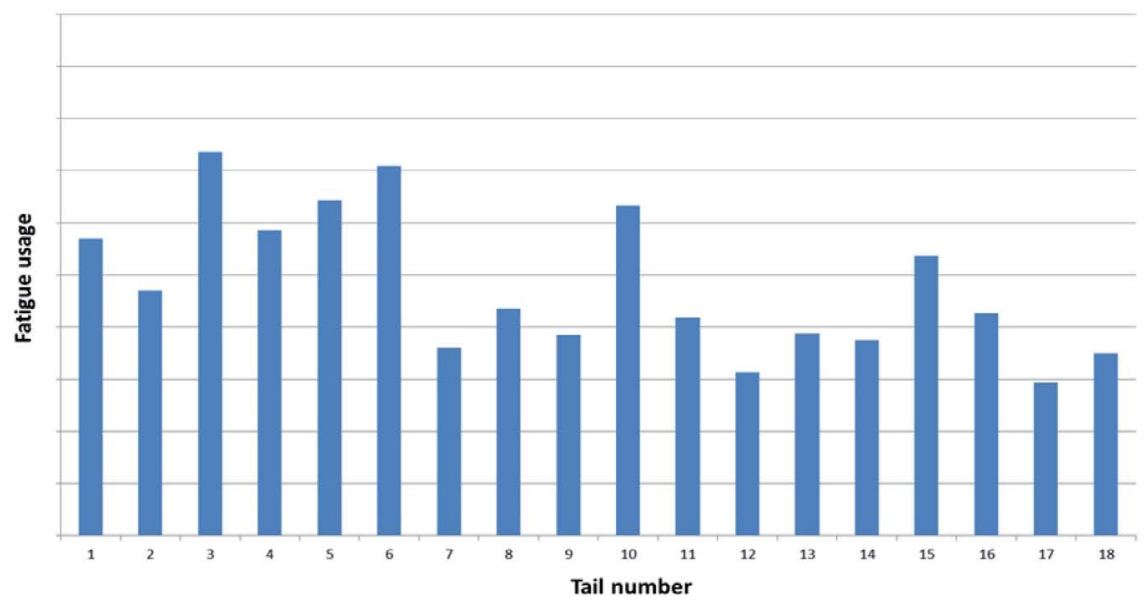

Fig. 2. Total damage indexes for the aircraft fleet 


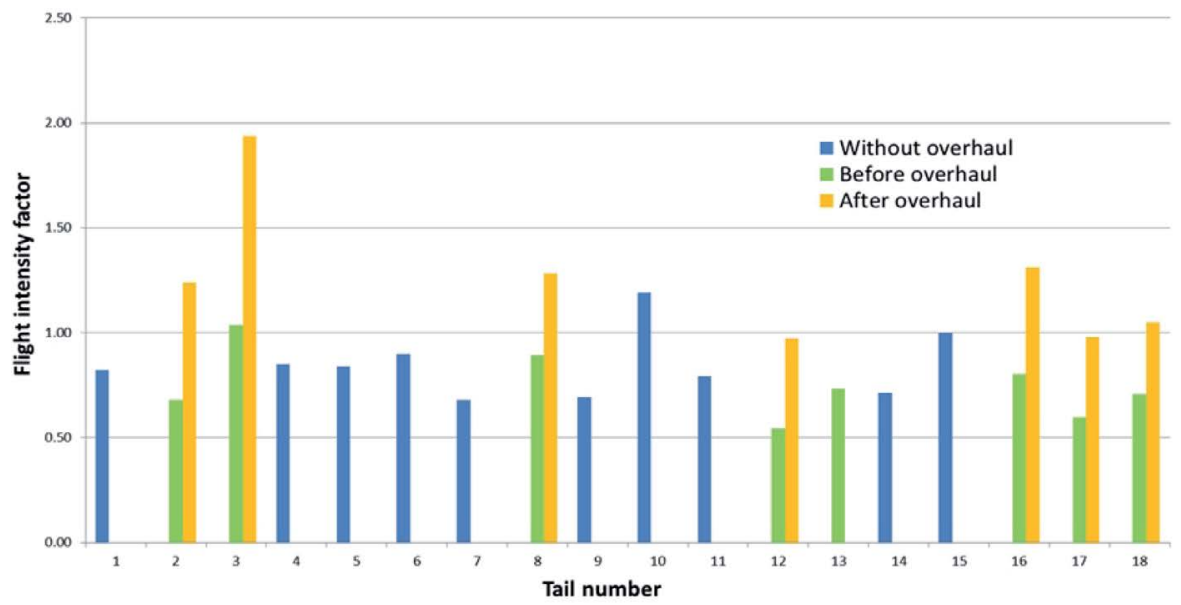

Fig. 3. Flight intensity factors $\left(K_{i e}\right)$ before and after overhaul

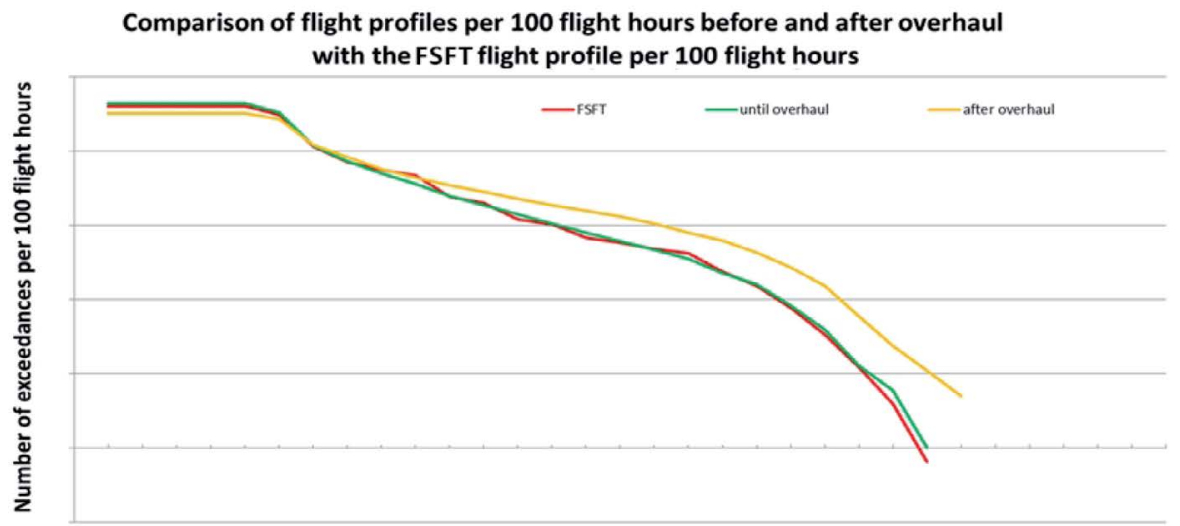

G factor exceedances

Fig. 4. Comparison of flight profiles before and after overhaul to the nominal profile

\section{SUMMARY}

In this paper, the authors presented the methodology of developing the IAT program for the Polish Su-22 fighter-bombers. The methodology is based on FSFT results, basic fatigue theorems [4-8] and actual flight data recorded by an onboard flight data recorder.

The preliminary results show, that the program allows the evaluation of the condition of individual aircraft to define the overall status of the whole fleet. Moreover, the estimation of the residual fatigue life in terms of EFH as well as definition of flight intensity factor for each aircraft allow for maintenance and retirement planning.

Further work will focus on evaluating consequent operational data and on introducing any adjustments to the model that might be necessitated by significant changes to the fleet flight profile. 


\section{REFERENCES}

[1] P. Reymer, A. Leski, W. Zieliński, K. Jankowski, Full Scale Fatigue Test concept of a Su-22 fighter bomber, Fatigue of Aircraft Structures, vol. 6, pp. 79-87, Warszawa 2015.

[2] A. Leśniczak, P. Reymer, Warunki Techniczne WT-129/31/2014, Warunki techniczne nr WT-129/31/2014 do wykonania próby zmęczeniowej samolotu Su-22 UM3K nr 68507, ITWL, Warszawa, 2014.

[3] Ł. Kornas, Sprawozdanie SP-32/31/2016, Opracowanie i analiza wyników badań nieniszczacych (etap I, II, III, IV) samolotu Su-22UM3K nr 68507 po zrealizowaniu petnoskalowej próby zmęczeniowej, ITWL, Warszawa, 2016.

[4] Miner, M. A. 'Cumulative damage in fatigue', J. appl. Mech., Trans. Am. Soc. mech. Engrs 1945 67, A-159

[5] Мыльников, В.В. Связь параметра сопротивления усталости с повреждаемостью поверхности стали 30ХГСН2А // Сборник научных

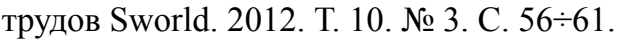

[6] В.В. Мыльников, М.В. Мыльникова, Е.А. Чернышов, Д.И. Шетулов, Е.С. Беляев. Анализ изменения показателей сопротивления усталости сталей и титановыхсплавов в зависимости от физическихпроцессов, протекающих на их поверхности. Russian Journal of Nonferrousmetals. - 2010. - Vol. 51. - № 3. - pp. $237 \div 242$.

[7] Ромашев М.А. Изменение структуры и повреждаемости поверхности стали в процессе ииклического нагружения и их взаимосвязь с показателями сопротивления усталости. Успехи современного естествознания. - 2015.

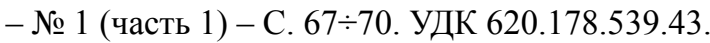

[8] Smith, K. N., P. Watson, and T. H. Topper, A Stress-Strain Function for the Fatigue of Metals," Journal of Materials, ASTM, Vol. 5, No. 4, Dec. 1970, pp. 767-778.

[9] K. Jankowski, W. Zieliński, P. Reymer, Sprawozdanie SP-62/31/2015, Analiza wyników skalowania kanałów tensometrycznych samolotu Su-22UM3K nr 67310, ITWL, Warszawa, 2015.

[10] M. Woch, Ł. Obrycki, Sprawozdanie SP-40/31/2015, Analiza wartości przeciażeń pionowych samolotów Su-22M4 oraz Su-22UM3Kw różych fazach lotu na podstawie zapisów pokładowych rejestratorów parametrów lotu TESTER U3E, ITWL, Warszawa, 2015. 